\title{
Nilai Budaya dan Sistem Kepercayaan dalam Legenda Raden Ayu Oncattondo Wurung: Kajian Folklor
}

\author{
Icha Fadhilasari $^{1}$ | Mohamad Nizar Rahmanto ${ }^{2}$
}

${ }^{1}$ Prodi Sastra Indonesia UIN Sunan Ampel Surabaya

${ }^{2}$ Prodi Sejarah Peradaban Islam UIN Sunan Ampel Surabaya

Correspondence:

Icha Fadhilasari

Prodi Sastra Indonesia UIN Sunan Ampel Surabaya ichafadhilasari12@gmail.com

Article History:

Received 11 August 2020

Revised 26 April 2021

Accepted 27 April 2021

\section{Abstract}

As part of folklore, legend is not only describes the collective stories of a group of people but also contains historical elements. Legends can reflect the culture of a cultural community. The legend of Raden Ayu Oncattondo Wurung is one of the folklore that is still believed by some people around Sidoarjo. This study aims to describe the functions, cultural values and belief systems of the figure of Raden Ayu Oncattondo Wurung related to the community in Terung Wetan, Krian, Sidoarjo. This research uses a qualitative-descriptive method. In data collection, observations and interviews were carried out with several community leaders and local residents. The results show the origins of Raden Ayu Oncattondo Wurung. Furthermore, it can be understood the functions, cultural values and belief systems associated with the legend in relation to the local community. This legend has two functions that regulate human behavior in people's lives. The cultural values in the legend become a reference for the behavior of the local community. Cultural values in this study are focused on spiritual values, namely: 1) truth, 2) esthetic, 3) goodness, and 4) religious values.

Keywords:

Oncattondo Wurung, Putri Terung, Terung Wetan, legend, folklore

\section{Abstrak}

Legenda merupakan bagian dari folklor lisan yang tidak hanya menggambarkan kisah-kisah kolektif suatu kelompok masyarakat tetapi juga mengandung anasir sejarah. Legenda dapat mencerminkan kebudayaan sebuah komunitas kultural. Legenda Raden Ayu Oncattondo Wurung merupakan salah satu folklor lisan yang masih diyakini oleh sebagian masyarakat di sekitar Sidoarjo. Penelitian ini bertujuan untuk mendeskripsikan fungsi, nilai budaya dan sistem kepercayaan pada sosok Raden Ayu Oncattondo Wurung terkait masyarakat di Terung Wetan, Krian, Sidoarjo. Penelitian ini menggunakan metode kualitatif-deskriptif. Dalam pengumpulan data dilakukan pengamatan dan wawancara kepada beberapa tokoh masyarakat dan warga setempat. Hasilnya diketahui asal-usul Raden Ayu Oncattondo Wurung. Selanjutnya, dapat dipahami fungsi, nilai budaya dan sistem kepercayaan terkait legenda tersebut sehubungan dengan masyarakat setempat. Legenda tersebut memiliki dua fungsi yang mengatur perilaku manusia dalam kehidupan masyarakat. Nilai budaya pada legenda tersebut menjadi acuan tingkah laku masyarakat setempat. Nilai budaya dalam penelitian ini difokuskan pada nilai rohani, yakni: 1) kebenaran, 2) keindahan, 3) kebaikan, dan 4) nilai religius.

Kata Kunci:

Oncattondo Wurung, Putri Terung, Terung Wetan, legenda, folklor 


\section{Pendahuluan}

Kemajemukan Indonesia tidak hanya tampak dari bahasa, budaya, ras, suku bangsa dan sistem kepercayaan masyarakatnya (Rahardjo, 2010). Keanekaragaman kawasan Nusantara juga muncul dari pelbagai indikator kultural lain, dan salah satu yang menonjol adalah folklor. Folklor yang berkembang dalam masyarakat dihasilkan oleh suatu sistem yang terikat pada nilai kultural dengan pelbagai bentuk dan jenis (Endraswara, 2013). Bentuk-bentuk folklor terdiri atas (1) lisan, seperti bahasa rakyat, sajak dan puisi rakyat, legenda, mite, dongeng, nyanyian rakyat yang kesemuanya berbentuk dan diwariskan secara lisan; (2) sebagian lisan, seperti kepercayaan rakyat, permainan rakyat, kesenian rakyat yang diwariskan dalam bentuk setengah lisan; dan (3) nonlisan, seperti kuliner rakyat yang diwariskan dalam bentuk bukan lisan, berupa benda dan peninggalan-peninggalan kebudayaan (Anton \& Marwati, 2015; Danandjaja, 1984; Harvilahti, 2004; Mulder, 1990).

Keberadaan folklor dalam suatu lokus kultural memberikan gambaran kondisi riil masyarakat pemilik kebudayaan lisan tersebut. Dengan kata lain, tradisi lisan merupakan manifestasi sebuah sistem kepercayaan kolektif serta tradisi kultural yang berkembang sebagai wujud dari respon masyarakat terhadap folklor tersebut (Hutomo, 1991). Dalam tulisan ini folklor diandaikan sebagai sistem memori kolektif dan menjadi skema kultural penduduk pemilik folklor. Objek folklor yang dimaksud dalam tulisan ini adalah legenda Raden Ayu Oncattondo Wurung (Putri Terung) dalam kaitanya dengan masyarakat Terung Wetan, Krian, Sidoarjo sebagai masyarakat pemilik folklor tersebut.

Keberadaan situs Terung tidak bisa dilepaskan dari konteks historis ${ }^{1}$ yang melekat pada sosok putri Raden Husein, adipati Terung dari masa akhir kekuasaan Majapahit (1478-1526) ${ }^{2}$ (Fitrotin \& Suparwoto, 2014; Sukmawati \& Sulistiani, 2015). Dalam hal ini, kontroversi seputar kematian Putri Terung yang mendadak hamil tanpa keberadaan sosok suami memiliki signifikansi dan bahkan menentukan keberadaan legenda, artefak arkeologis, serta petilasan Putri Terung dan bapaknya sebagai situs yang menarik minat peziarah untuk mengunjungi situs Terung di Krian, Sidoarjo (Faizah, 2014; Rahmawati, 2016).

Sebagai situs yang menarik minat para peziarah, keberadaan sosok legendaris tidak bisa dilepaskan dari nilai-nilai budaya yang melekat pada Putri Terung. Raden Ayu Oncattondo Wurung yang memiliki nama lain, seperti Raden Ayu Sundari Cempokowati atau Kenconowati atau Endang Lukitosari dan Raden Ayu Putri Pecattondo Terung diyakini oleh masyarakat sekitar, dalam hal ini penduduk desa Terung Wetan, Krian, Sidoarjo $^{3}$ sebagai pelambang lokus kultural dan membentuk identitas Terung. Dalam hal itu, nilai budaya merupakan konsep abstrak mengenai masalah besar dan bersifat umum yang sangat penting serta bernilai bagi kehidupan masyarakat. Nilai budaya menjadi acuan tingkah laku sebagian besar anggota masyarakat bersangkutan. Yang mempengaruhi alam pikiran mereka dan sulit untuk diterangkan secara logis atau rasional. Nilai budaya bersifat langgeng, tidak mudah berubah ataupun tergantikan dengan nilai budaya yang lain (Arifin, 2016; Yusuf \& Fidyansari, 2017).

Selain nilai budaya, folklor menjadi manifestasi dari suatu sistem kepercayaan penduduk setempat dan sekitarnya. Dalam hal itu, kepercayaan merupakan sistem keyakinan atau sesuatu hal yang diyakini keberadaan atau kebenarannya dari suatu kelompok manusia yang berdiri atas suatu landasan yang menjelaskan cerita-cerita yang suci, yang berhubungan dengan masa lalu (Firmansyah, 2017). Sedangkan "kepercayaan rakyat" atau 
sering disebut takhayul merupakan kepercayaan yang oleh kalangan terdidik Barat (rasionalempiris) dianggap sebagai pengetahuan sederhana bahkan pandir, tidak berdasarkan logika, sehingga kepercayaan yang dilabeli takhayul tersebut dianggap tidak dapat dipertanggungjawabkan secara ilmiah (Danandjaja, 1984).

Folklor dalam penelitian ini tergolong sebagai folklor lisan. Folklor lisan yang dimaksud adalah legenda Raden Ayu Ocottanda Wurung yang hamil secara misterius setelah memangku pisau (pangot) yang dipinjam dari seorang pemuda. Karena kehamilannya, Putri Terung akhirnya meregang nyawa di tangan ayahnya, yaitu Raden Husein (Kusen) yang tak lain adalah adipati wilayah Terung (Fitrotin \& Suparwoto, 2014). Dari legenda tersebut muncul sebuah kepercayaan kolektif masyarakat sekitar Terung Wetan, Krian, Sidoarjo bahwa seseorang yang masih gadis tidak diperbolehkan (baca: tabu) untuk meletakkan pisau di pangkuan. Akhinya memangku pisau bagi seorang gadis di Terung Wetan dan sekitarnya dianggap kurang sopan. Sedangkan pemilihan objek kajian, yakni legenda Raden Ayu Oncattondo Wurung didasarkan pertimbangan folklor lisan ini dipercaya dan memiliki dimensi religius oleh masyarakat Sidoarjo yang tampak dari antusiasme peziarah ke situs Terung, Krian, Sidoarjo. Oleh sebab itu hal yang berkenaan dengan objek ziarah, terutama legenda seputar Putri Terung menjadi relevan untuk diidentifikasi. Kerja ilmiah ini sebagai langkah konkret untuk menyelamatkan, memelihara, dan bahkan mengembangkan warisan kultural sebagai wujud pembinaan dan pemeliharaan nasional, yakni berupa identitas ikonik yang terikat pada suatu daerah (Setiawan, Tallapessy, \& Subaharianto, 2016), dalam konteks tulisan ini adalah masyarakat Sidoarjo dan sekitarnya.

\section{Metode Penelitian}

Penelitian ini menggunakan metode kualitatifdeskriptif. Pendekatan kualitatif dimanfaatkan sebagai prosedur penelitian yang menghasilkan data deskriptif berupa kata-kata lisan atau tertulis dari orang-orang dan perilaku yang dapat diamati. Selain itu, metode ini digunakan untuk menganalisis latar belakang legenda "Raden Ayu Oncattondo Wurung" sehubungan kepercayaan yang timbul dan berkembang dalam masyarakat setempat. Pemilihan desain studi ini dikarenakan penelitian kualitatif mendeskripsikan interaksi yang terjadi antara narasumber dan peneliti terkait legenda Raden Ayu Oncattondo Wurung.

Data dalam penelitian ini berupa cerita lisan seputar legenda Raden Ayu Oncattondo Wurung yang didapatkan dari wawancara dengan narasumber. Data primer tersebut lalu dicari relasinya dengan fungsi, nilai budaya dan sistem kepercayaan pada masyarakat setempat. Sumber data dalam penelitian ini adalah informan, yaitu Juru Kunci makam Raden Ayu Oncattondo Wurung, serta sebagian masyarakat lokal di Terung Wetan, Krian, Sidoarjo yang masih memahami dan mengerti seluk beluk legenda Raden Ayu Oncattondo Wurung.

Teknik pengumpulan data yang digunakan, meliputi: (a) observasi atau pengamatan di Terung Wetan, terutama sekitar makam Putri Terung untuk menggali informasi tentang legenda putri adipati Terung; (b) wawancara, peneliti menggali informasi seputar narasumber yang mengetahui seluk beluk legenda Raden Ayu Oncattondo Wurung untuk dilakukan wawancara secara mendalam. Peneliti melakukan wawancara menggunakan bantuan pertanyaan-pertanyaan yang dibuat berdasarkan observasi yang sudah dilakukan sebelumnya. Peneliti mengumpulkan informasi melalui wawancara dengan juru kunci makam, serta beberapa orang warga setempat; 
(c) perekaman, penelitian ini digunakan teknik perekaman dalam konteks tak asli, dimana teknik perekaman digunakan dalam penelitian ini agar didapatkan data yang berkaitan dengan legenda Raden Ayu Oncattondo Wurung. Maksud peneliti menggunakan teknik wawancara tak asli adalah perekaman dilakukan tanpa ada campuran unsurunsur lain, misalnya tepuk tangan, suara penonton, dan lain-lain; (d) pencatatan, teknik pencatatan dalam penelitian ini dilakukan dengan mencatat hal-hal yang dianggap penting yang belum terekam.

Pada tahap berikutnya, peneliti menganalisa data menggunakan teknik pemaparan dan deskripsi umum. Setelah mendapatkan data-data primer dari hasil wawancara dan observasi, penulis merangkum dan menyusun data-data tersebut sesuai urutan dan kebutuhan peneliti. Peneliti juga menggunakan perbandingan dari beberapa penelitian yang telah dilakukan sebelumnya. Dalam sesi wawancara, penulis membandingkan hasil wawancara seorang narasumber dengan narasumber lainnya, hal tersebut dilakukan semata untuk menemukan sumber data yang valid. Secara rinci, langkah-langkah analisis data sebagai berikut: (1) transkripsi data legenda Raden Ayu Oncattondo Wurung, (2) identifikasi tentang fungsi, nilai budaya, dan sistem kepercayaan, (3) klasifikasi data, yaitu data yang sudah didapatkan lantas dikalsifikasikan atau digolongkan, (4) interpretasi, (5) pengambilan kesimpulan mengenai fungsi, nilai budaya, dan sistem kepercayaan dalam legenda Raden Ayu Oncattondo Wurung.

\section{Hasil dan Pembahasan}

Penelitian ini mengenai legenda Raden Ayu Oncattondo Wurung yang terletak di desa Terung Wetan, Krian, Sidoarjo. Desa Terung Wetan, Krian, Sidoarjo saat ini merupakan bagian dari sebuah kadipaten yang di masa Majapahit merupakan wilayah Terung (Trung), satu di antara tiga penyeberangan utama selain Surabaya (Curabhaya) dan Trowulan (Canggu). Pada masa ini wilayah Terung terbagi menjadi dua wilayah administratif desa, yakni Terung Wetan dan Terung Kulon (Fitrotin \& Suparwoto, 2014).

Cerita rakyat seputar Raden Ayu Oncattondo Wurung atau Putri Terung berikut didasarkan pada penuturan juru kunci makam situs Terung, sebagai berikut:

Menjelang keruntuhan kekuasaan Majapahit, Terung dipimpin oleh seorang adipati beragama Islam, yakni Raden Husein. Terung berasal dari kata curung yang artinya bengawan, didasarkan pada bengawan yang berada di bawah jembatan Kepuh Kembar. Bengawan tersebut oleh masyarakat setempat dikenal dengan sebutan Bengawan Terung.

Pada masa kekuasaan Majapahit bengawan ini digunakan sebagai tempat pemberhentian kapalkapal dagang. Konon di pelabuhan Terung terdapat sebuah pohon yang tumbuh yang oleh masyarakat setempat disebut Kepuh Kembar. Pohon tersebut berfungsi sebagai pengikat tali kapal-kapal yang hendak bersandar. Bengawan Terung demikian tempat ini disebut merupakan pelabuhan besar yang digunakan sebagai persinggahan kapal-kapal para saudagar yang membawa komoditas dari luar menuju pedalaman Jawa atau sebaliknya dan pasti melawati wilayah Terung.

Raden Husein memiliki empat orang istri yaitu Nyai Wilis, Mas Ayu Cendana Bhre Pakembangan, Nyai Wonokromo, dan Nyai Mertasari. Raden Kusen memiliki tujuh putra dan tiga putri. Salah satu putri adipati Terung tersebut bernama Raden Ayu Putri Oncattondo Wurung, dari istri kedua, Mas Ayu Cendana. Raden Ayu Oncattondo Wurung merupakan putri ketiga dari tiga bersaudara, yaitu Mas Ayu Kriyan, dan Mas Ayu Winong. Raden Ayu Oncattondo Wurung yang juga dikenal sebagai 
Putri Terung memiliki sifat dan karakteristik yang sangat disegani oleh masyarakat setempat. Wataknya yang lemah lembut, tutur bahasa yang halus dan sopan. Wajahnya yang rupawan diimbangi sikap yang membaur dengan masyarakat setempat walaupun dirinya merupakan anak seorang aristokrat serta dikenal patuh terhadap orang tuanya.

Pada masa kecil Putri Terung senang bermain dengan anak-anak dari penduduk sekitar Terung seperti dodolan pasaran. Pada saat remaja Putri Terung senang berjualan kembang. Suatu ketika Raden Kusen diberi tugas untuk pergi ke Blambangan oleh Kesultanan Demak Bintoro ${ }^{4}$ untuk mencari pusaka kerajaan yakni pusaka dapur sangkelat yang hilang dicuri oleh pihak Blambangan.

Putri Terung tetap melakukan aktivitas seperti biasa. Dia berjualan kembang ke pasar Terung. Namun dalam perjalanan Putri Terung sadar jika dirinya lupa membawa pisau (pongot) untuk memotong daun pandan (boreh). Dalam keadaan bingung muncul seorang pemuda tampan yang membawah belati yang dibutuhkan oleh Putri Terung untuk memotong daun pandan dagangannya. Pemuda tampan tersebut oleh sebagian orang diyakini adalah Raden Makdum Ibrahim atau Sunan Bonang, ${ }^{5}$ putra Sunan Ampel yang hendak membeli kembang dagangan Putri Terung.

Kemudian Putri Terung berinisiatif untuk meminjam pisau milik pemuda tersebut. Dipinjamkanlah pisau milik pemuda itu kepada Putri Terung dengan syarat pisau itu tidak boleh dipangku. Namun lantaran asyik menyiapkan kembang tanpa disengaja Putri Terung meletakkan pisau tersebut di pangkuannya. Secara ajaib dan secepat kilat pisau tersebut hilang dari pangkuan Putri Terung. Secara bersamaan pula pemuda tampan yang meminjamkan pisau raib dari hadapan Putri Terung.

Tak berselang lama, perut Putri Terung membesar. Kian hari perut puti kian membesar, laksana ia sedang mengalami kehamilan. Nahas, sepulang Raden Kusen dari tugasnya, betapa terkejut dan marahnya ia melihat dengan mata kepalanya sendiri bahwa putrinya hamil. Kendatipun sudah dijelaskan oleh Putri Terung ihwal kejadian saat berjualan bunga, tetapi Raden Kusen bergeming dan tidak percaya dengan pengakuan putrinya. Demi mempertahankan martabatnya sebagai seorang adipati, Raden Kusen bersumpah atau nibakno sabdo bahwa dirinya akan mengukum putrinya dengan hukuman mati menggunakan pusaka korowalang. Putri Terung lantas menerima hukuman tersebut dengan permohonan, jika nanti setelah dieksekusi darahnya berbau wangi dan berwarna putih, pertanda bahwa Putri Terung masih suci dan tidak bersalah. Putri Terung juga meminta jasadnya dibuang ke bengawan Terung. Apabila jasadnya melawan arus, hal itu sebagai bukti bahwa dirinya tidak bersalah. Menurut cerita, saat eksekusi mati pada hari anggoro kasih (selasa kliwon), darah Putri Terung berwarna putih dan berbau wangi. Namun hendak apa dikata, eksekusi dilakukan dan akhirnya Raden Kusen menyesali kecerobohannya.

Kuburan Raden Ayu Oncattondo Wurung terletak di tengah-tengah hutan bambu yang tidak terawat. Seorang penduduk asli setempat dari desa Terung Wetan yang baru pulang dari mondok di Kediri yang dipercayai memiliki semacam indera keenam, beliau melihat kuburan Putri Terung di tengah-tengah hutan bambu dan tidak terawat. Setelah melihat keadaan tersebut, beliau mengajak para pemuda-pemudi untuk melestarikan budaya kuno Putri Terung. Sejak itu banyak peziarah mengunjungi makam Putri Terung dari daerah setmpat dan sekitar, bahkan beberapa dari mereka berasal dari luar daerah Sidoarjo. 
Terkait folklor lisan seputar Raden Ayu Oncattondo Wurung di atas, motif peziarah mengunjungi petilasan Putri Terung dan artefak arkeologis yang berkenaan dengan Putri Terung bukan hanya terpusat pada kekeramatan Putri Terung yang tampak dalam proses kematiannya. Hal yang berkenaan dengan folklor lisan Putri Terung terkait dengan nilai-nilai yang terikat pada sosok ini. Pada bagian berikut akan dijabarkan ihwal yang terkait Raden Ayu Oncattondo Wurung yang dikenal legendaris dan keramat tersebut.

\section{Fungsi Legenda Raden Ayu Oncattondo}

\section{Wurung}

Sebagaimana diungkapkan Bascom (1954), bahwa semua bentuk prosa rakyat memiliki beberapa fungsi, antara lain sebagai sistem proyeksi bagi pemilik folklor, alat pengesahan pranata dan lembaga kebudayaan, alat pendidikan anak (pedagogi), alat kendali masyarakat, dan penghibur atau pelipur lara (Danandjaja, 1984; Mashuri \& Alfin, 2020). Legenda sebagai bagian dari prosa rakyat memiliki fungsi untuk meneguhkan kebenaran takhayul atau kepercayaan rakyat. Legenda perseorangan merupakan cerita tentang tokoh-tokoh tertentu, yang dianggap oleh empunya cerita benar-benar pernah terjadi (Danandjaja, 1984). Karena posisi cerita rakyat yang demikian, tentu dibutuhkan penggalian pada cerita rakyat Raden Ayu Oncattondo Wurung, terkait fungsinya sebagai alat pendidikan dan sarana hiburan penduduk setempat. Kedua fungsi tersebut akan dijabarkan sebagai berikut:

Sebagai bentuk hiburan, legenda Raden Ayu Oncattondo Wurung muncul dalam teknik dan motif penuturan legenda, utamanya kepadaanggota masyarakat yang tergolong sebagai generasi muda. Dalam hal ini penceritaan legenda sebagai representasi budaya lisan (folklor) merupakan medium untuk memberikan hiburan masyarakat agraris yang guyub dan komunal. Sebagai sebuah komunitas kultural, sebuah hiburan tidak hanya bersifat lucu, tetapi juga mengandung sesuatu yang memberikan pengetahuan. Selain itu, narasumber mengatakan legenda ini sering digunakan sebagai sarana hiburan, dijadikan sebuah lakon pertunjukan teater oleh beberapa kelompok teater sekolah di sekitar wilayah Krian.

Sedangkan sebagai sarana pendidikan, legenda Raden Ayu Oncattondo Wurung ini dapatdigunakan sebagai alat pedagogi. Alasannya, legenda ini memberikan wawasan atau pemahaman untuk mendidik audiens (pendengar atau penonton) agar senantiasa mawas diri atau waspada atas segala konsekuensi dari sesuatu yang dikerjakan.

"Namun, lantaran asyiknya Raden Ayu menyiapkan kembang, ia tanpa sengaja meletakkan pisau itu di pangkuannya. Dan secepat kilat, secara ghaib, pisau itu hilang secara bersamaan dengan Pemuda tampan tersebut."

Nukilan cerita di atas dapat dipahami jika segala nasib buruk yang menimpa Putri Terung berawal dari kecerobohannya sendiri. Dengan menyimak legenda ini, diharapkan para audiens mampu mengevaluasi diri agar senantiasa mawas diri. Selain itu, legenda ini juga mengajarkan agar tidak mudah terpancing dan dikendalikan emosi. Karena jika seseorang dikendalikan emosi, justru akan menghadapi penyesalan.

"Menurut cerita, saat eksekusi mati pada hari anggoro kasih (selasa kliwon), tiba-tiba darah Raden Ayu berwarna putih dan berbau wangi. Namun hendak apa dikata, Raden Kusen hanya bisa menyesali perbuatannya."

Kutipan di atas mengajarkan setiap tindakan yang didasari emosi, bukan logika akan berujung pada penyesalan. Dengan demikian, legenda ini mempunyai sarana pendidikan agar manusia 
senantiasa mawas diri dan menjauhkan segala tindakan kita dari amarah.

Beralih pada fungsi selanjutnya, yaitu sebagai alat pemaksa dan pengawas agar norma-norma masyarakat dipatuhi anggota kolektifnya. Hal ini penting untuk dipahami sebagai fungsi yang tetap menjadi pegangan setiap masyarakat dalam berkehidupan. Karena norma-norma tersebut sangat penting sebagai tradisi yang harus dipertahankan. Bagi masyarakat Terung Wetan yang menjadi alat pemaksa dan pengawas agar masyarakat selalu patuh oleh anggota kolektifnya adalah larangan memangku pisau (pongot). Didalam legenda tersebut memangku pisau mengakibatkan Raden ayu hamil.

"ia tanpa sengaja meletakkan pisau itu di pangkuannya. Dan secepat kilat, secara ghaib, pisau itu hilang secara bersamaan dengan Pemuda tampan tersebut. Setelah kejadian itu, Perut Raden Ayu kian hari kian membesar, laksana ia sedang mengalami kehamilan. Naas, sepulang Raden Kusen dari tugasnya, betapa terkejut dan marahnya ia melihat dengan mata kepalanya sendiri bahwa putrinya sedang hamil."

Kutipan tersebut menggambarkan bahwa Raden Ayu hamil setelah memangku pisau dari pemudan tampan. Hal tersebut menjadi norma di dalam masyarakat untuk tidak memangku pisau (pongot) dikarenakan takut mendapat celaka. Karena memangku pisau juga sangat bahaya bisa melukai tubuh kita.

\section{Nilai Budaya dalam Legenda Raden Ayu Oncattondo Wurung}

Nilai budaya merupakan konsep abstrak mengenai masalah besar dan bersifat umum yang sangat penting serta bernilai bagi kehidupan masyarakat. Nilai budaya menjadi acuan tingkah laku sebagian besar anggota masyarakat yang bersangkutan (Arifin, 2016). Koentjaraningrat
(2002) mengelompokkan nilai budaya berdasarkan hubungan manusia, antara lain: (1) hubungan dengan Tuhan, (2) hubungan dengan alam, (3) hubungan dengan masyarakat, (4) hubungan dengan manusia, dan (5) hubungan dengan diri sendiri. Dalam tulisan ini nilai budaya difokuskan pada nilai rohani sebagaimana dirumuskan oleh Notonegoro (1975), yakni 1) kebenaran, 2) keindahan, 3) kebaikan, dan 4) religiusitas.

Nilai Kebenaran adalah nilai yang dianggap benar dan dapat dihubungkan dengan akal dan pengetahuan manusia. Hal tersebut dapat dilihat pada kutipan berikut:

"Kemudian Raden Ayu berinisiatif untuk meminjam pisau kepada pemuda itu. Dipinjamkanlah sebuah pisau kepada Raden Ayu dengan syarat pisau itu tidak boleh diletakkan di pangkuannya."

Dari kutipan di atas, bisa kita lihat bahwa larangan pemuda terhadap Putri Terung, jika dihubungkan dengan akal dan pengetahuan manusia adalah: jika sebuah pisau ditelakkan di pangkuan (dalam posisi duduk) maka hal tersebut dapat membahayakan diri kita. Bisa melukai kaki, bahkan perut apabila tidak diletakkan dengan benar, atau bergerak berlebihan.

Nilai keindahan yang tampak pada legenda Raden Ayu Oncattondo Wurung adalah cara narasumber bercerita. Setiap narasumber memiliki cara dan gaya tersendiri dalam menceritakan sebuah legenda (prosa rakyat), sehingga pendengar merasa tertarik untuk mengetahui isi ceritanya. Dalam legenda Raden Ayu Oncattondo Wurung terdapat suatu perilaku yang dianggap terpuji atau baik bagi masyarakat. Nilai kebaikan tersebut muncul dari penggambaran perilaku Putri Terung, serta bagaimana kepatuhan seorang Putri Terung terhadap segala perintah ayahnya.

"Raden Ayu Oncattondo Wurung memiliki sifatatau karakteristik yang sangat disegani oleh masyarakat 
desa. Wataknya yang lemah lembut, tutur bahasanya halus dan sopan. Wajahnya yang rupawan, sikapnya yang mau membaur dengan masyarakat setempat walaupun ia anak adipati serta Ia patuh terhadap orang tuanya."

Dalam kutipan di atas dapat diambil pelajaran bahwa kebaikan diri dari sikap yang digambarkan pada tokoh Putri Terung. Selain itu kepatuhan yang tinggi juga tercermin dalam bagian akhir kisah, di mana Putri Terung dengan ikhlas menerima hukum pati yang dijatuhkan oleh bapaknya sendiri. Nilai Religius merupakan nilai ketuhanan, kerohanian yang tertinggi dan mutlak, nilai religius bersumber pada kepercayaan. Nilai religius berkaitan dengan kepercayaan terhadap Tuhan. Namun di dalam legenda Raden Ayu Oncattondo Wurung, hampir tidak ditemukan nilai religius yang menjurus kepada Tuhan, melainkan nilai religius yang berkaitan dengan kepercayaan masa lampau, sebagai berikut:

"Setelah melihat keadaan tersebut, beliau mengajak para pemuda-pemudi untuk melestarikan budaya kuno Putri Terung Tersebut. Sejak itu banyak peziarah makam Putri Terung dari beberapa penjuru daerah."

Kutipan di atas menunjukkan bahwa masyarakat sekitar memiliki kepercayaan yang tinggi terhadap legenda ini. Dibuktikan dengan keperdulian mereka terhadap makam yang dianggap milik Putri Terung.

\section{Bentuk Kepercayaan Legenda Raden Ayu Oncattondo Wurung}

Kepercayaan merupakan sistem keyakinan atau sesuatu hal yang diyakini keberadaan atau kebenarannya dari suatu kelompok manusia yang berdiri atas suatu landasaan yang menjelaskan cerita-cerita yang suci, yang berhubungan dengan masa lalu (Harsojo, 1977). Adapun kepercayaan rakyat atau sering disebut takhayul merupakan kepercayaan yang oleh orang berpendidikan Barat dianggap sederhana bahkan pandir, tidak berdasarkan logika, sehingga secara ilmiah tidak dapat dipertanggungjawabkan (Danandjaja, 1984).

Dalam kehidupan masyarakat Terung Wetan, Krian legenda Raden Ayu Oncattondo Wurung membawa serangkaian dampak yang mempengaruhi kehidupan mereka. Kehidupan keagamaan masyarakat Terung Wetan masih belum banyak dipengaruhi oleh budaya barat, hanya anak-anak muda saja yang dipengaruhi oleh budaya barat. Sedangkan kehidupan sosial budayanya masih melekat di desa ini. Di desa Terung Wetan penduduknya mayoritas beragama Islam, salah satu kewajiban bagi seluruh rakyat Indonesia untuk memeluk satu agama yang diyakininya. Selain itu sarana peribadatan di Terung Wetan sudah memadai untuk mendukung pelaksanaan ibadah sesuai dengan ajaran agama Islam.

Ditinjau dari segi budayanya, masyarakat Terung Wetan masih sangat kental dengan adat budaya setempat. Dalam hal ini penduduk setempat masih tergolong mempercayai hal-hal mistikatau ghaib dan tempat-tempat yang dianggap kramat, seperti makam Putri Terung. Tradisi lokal ini masih dipegang teguh oleh warga setempat namun budaya ini telah disusupi oleh nilai-nilai Islam. Sebagai contoh, jika sebuah keluarga hendak mengadakan acara atau hajatan, maka orang tua keluarga bersangkutan harus pergi ke makam Raden Ayu Oncattondo untuk meminta ijin dan mengharap berkah. Di desa ini penduduk kerapkali menyelenggarakan upacara adat seperti ruwat desa adan kleman. Pada hari kamis kliwon malam jumat legi, banyak juga yang menyelenggarakan bancaan di makam Raden Ayu Oncattondo dengan tujuan untuk berdoa kepada Tuhan Yang Maha Esa melalui perantaran Putri Terung untuk mengalab 
berkah. Ruwat Desa di Terung Wetan ini diadakan di areal makam Raden Ayu Oncattondo Wurung dengan nanggap wayang kulit, dan dilaksanakan serangkaian pesta atau kegiatan hiburan layaknya peringatan hari kemerdekaan.

Sementara itu, ditinjau dari segi keagamaan, masyarakat Terung Wetan memiliki tingkat kehidupan keagamaan yang kental dan rasa solidaritas yang tinggi. Masyarakat desa juga mempunyai kegiatan rutinitas di desa seperti Jam'iyah Kidul pada hari senin, pada hari rabu melaksanakan kegiatan manakib, pada hari kamis yasinan untuklaki-kali dan sebagainya. Haltersebut tidak lepas dari pengaruh legenda Raden Ayu Oncattondo Wurung. Didukung pula dengan masih banyaknya juru kunci atau sesepuh Terung Wetan yang memegang teguh nilai kepercayaan terhadap legenda ini. Walaupun mayoritas masyarakat Terung Wetan memeluk agama Islam, namun mereka semua tetap memandang keberadaan Putri Terung (baik makam maupun kisahnya) sebagai suatu hal yang wajib didahulukan. Oleh karena itu mereka kerapkali meminta izin terlebih dahulu kepada Putri Terung jika hendak melakukan kegiatan. Bukan untuk menyembah, melainkan dalam rangka nuwun sewu kepada danyang yang dianggap menjaga Terung Wetan.

\section{Percaya Terhadap Pamali dalam Bertindak}

Masyarakat Terung Wetan memiliki kepercayaan yang dipegang teguh sampai saat ini. Kepercayaan ini menyangkut kehidupan sehari-hari yang berfokus pada tingkah laku seorang perempuan. Masyarakat Terung Wetan menganggap bahwa meletakkan pisau (benda tajam) di atas pangkuan sebagai hal yang tabu, bahkan hal yang tidak boleh dilakukan oleh seorang perempuan, lebih-lebih perempuan yang masih gadis. Jika seorang gadis membangkang dan melakukan hal tersebut, konon ia akan mengalami kehamilan misterius walaupun ia belum pernah bersetubuh dengan lelaki manapun. Konon, dipercaya juga bahwa kehamilan itu nantinya hanya akan menjadi kehamilan ghaib, seolah-olah perempuan itu benar-benar mengandung namun ketika hendak dilahirkan justru isi kandungannya menghilang.

Kepercayaan ini bukan muncul tanpa sebab. Kepercayaan ini didasarkan pada kejadian yang menimpa Putri Terung. Yang harus mengalami kehamilan misterius setelah ia meletakkan sebuah belati di pangkuannya. Semenjak kisah legenda ini menyebar di masyarakat Terung Wetan, tetua desa dan masyarakat seolah langsung menganggap bahwa apa yang terjadi pada Putri Terung dapat menimpa pada masyarakat. Oleh karena itu kemudian masyarakat melarang keras tindakan tersebut terlebih kepada anak gadisnya.

Kepercayaan ini disebut oleh masyarakat Terung Wetan sebagai suatu yang gak ilok atau tidak sopan. Selain itu memang jika dikaitkan dengan logika, maka memangku sebuah pisau atau belati bisa mencelakakan diri kita. Apabila tanpa sengaja pisau itu menggores atau menusuk perut kita, ataupun melukai tubuh kita. Namun apapun itu, masyarakat Terung Wetan masih memegang teguh kepercayaan tersebut meskipun zaman sudah bergulir dan kehidupan makin menjadi modern.

\section{Percaya Kepada Makam Raden Ayu \\ Oncattondo Wurung}

Selain kepercaayaan dalam pamali, masyarakat Terung Wetan memiliki kepercayaan yang tinggi terhadap makam Raden Ayu Oncattondo Wurung. Dengan keberadaan makam di wilayah Terung Wetan masyarakat lebih percaya atas cerita Putri Terung. Setelah makam ini ditemukan oleh salah satu warga, kemudian dibangunlah sebuah pendopo atau bangunan yang digunakan sebagai 
tempat melindungi makam Putri Terung. Di kemudian hari tempat ini justru dijadikan tempat peribadatan bagi pengunjung yang hendak berdoa dan mengunjungi makam Putri Terung.

Hal ini membuat Putri Terung dikeramatkan oleh warga desa dan pengunjung yang datang ke makam tersebut. Warga desa kemudian juga menjadikan makam Putri Terung sebagai tempat untuk mencari izin atau restu tentang kegiatan apapun yang hendak dilakukan di desa Terung, khususnya Terung Wetan. Semisal, jika sebuah keluarga atau perangkat desa hendak mengadakan hajatan, maka orang tua mereka harus mendatangi makam Putri Terung untuk berdoa meminta ijin agar diberi kelancaran dan dijauhkan dari hambatan. Mereka percaya jika tidak melakukan izin terlebih dahulu kepada Putri Terung, maka kegiatan mereka tidak akan berjalan lancar. Ritus tersebut tetap dijalankan masyarakat setempat hingga kini. Namun dapat disimpulkan, bahwa kepercayaan ini semata-mata sebagai wujud penghormatan masyarakat Terung Wetan terhadap nenek moyang desa, terutama Putri Terung atau Raden Husein, bukan menyekutukan Tuhan Yang Maha Esa.

\section{Kesimpulan}

Berdasarkan analisis data dan pembahasan yang telah dilakukan di dalam penelitian ini dapat disimpulkan bahwa legenda Raden Ayu Oncattondo Wurung memiliki dampakyang signifikan di dalam kehidupan masyarakat Terung Wetan. Dampak ini muncul dari nilai-nilai budaya dalam legenda tersebut. Sedangkan kepercayaan yang timbul berakar dari kepercayaan masyarakat terhadap legenda Putri Terung. Nilai budaya yang terdapat dalam legenda Raden Ayu Oncattondo Wurung difokuskan kepada nilai rohani, yakni kebenaran, keindahan, kebaikan, dan religius. Dengan nilai kebaikan yang lebih menonjol, berupa wujud kebaikan sifat Putri Terung dari pengungkapannya di dalam kisah legenda setempat. Sistem kepercayaan yang timbul dari legenda tersebut merupakan kepercayaan masyarakat terhadap tindakan yang mampu membawa dampak buruk dalam kehidupan (pamali, gak ilok). Serta kepercayaan yang timbul atas dasar penghormatan kepada roh leluhur demi keselamatan hidup di dunia.

\section{Daftar Pustaka}

Anton, \& Marwati. (2015). Ungkapan Tradisional dalam Upacara Adat Perkawinan Masyarakat Bajo Pulau Bulu Kabupaten Muna Barat. Jurnal Humanika, 3(15).

Arifin, M. N. (2016). Nilai-nilai Budaya dalam Pengajaran Bahasa di Sekolah. Reseachgate.

Bascom, W. R. (1954). Four Functions of Folklore. The Journal of American Folklore, 67(266). https://doi. org/10.2307/536411

Danandjaja, J. (1984). Folklor Indonesia: Ilmu Gosip, Dongeng, dan Lain-lain. Jakarta: Grafiti Pers.

Dhavamony, M. (1995). Fenomenologi Agama. Yogyakarta: Kanisius.

Endraswara, S. (2013). Folklor Nusantara: Hakikat, Bentuk, dan Fungsi. Yogyakarta: Penerbit Ombak. Faizah, N. (2014). Tradisi Ziarah Makam Putri Terung di Desa Terungwetan Kecamatan Krian Kabupaten Sidoarjo (UIN Sunan Ampel Surabaya). Retrieved from http://digilib.uinsby.ac.id/906/ Firmansyah, A. T. (2017). Analisis Kepercayaan Tokoh Pada Novel Tambora Karya Agus Sumbogo Tinjauan Teori Antropologi Sastra (Universitas Muhammadiyah Malang). Retrieved from http:// eprints.umm.ac.id/38805/ 
Fitrotin, N. F., \& Suparwoto. (2014). Kedudukan Daerah Terung (Krian-Sidoarjo) Pada Masa Menjelang Ahir Majapahit (1478-1526). AVATARA, e-Journal Pendidikan Sejarah, 2(1).

Hanafiah, D., \& Soetadji, N. S. (1996). Perang Palembang Melawan VOC. Palembang: Penerbit Karyasari. Harsojo, H. (1977). Pengantar Antropologi. Jakarta: Binacipta.

Harvilahti, L. (2004). Folklore and Oral Tradition. Oral Tradition, 18(2). https://doi.org/10.1353/ ort.2004.0065

Hutomo, S. H. (1991). Mutiara Yang Terlupakan: Pengantar Studi Sastra Lisan. Surabaya: HISKI Komisariat Jawa Timur.

Koentjaraningrat, K. (2002). Kebudayaan, Mentalitas, dan Pembangunan. Jakarta: PT. Gramedia.

Krisna, B. A. (2011). Ensiklopedi Raja- Raja Jawa. Yogyakarta: Araska.

Malinowski, B. (1954). Megic, Science and Religion. New York: Daubleday Anchor Book.

Mashuri, M., \& Alfin, J. (2020). Genealogi Wabah dalam Cerita-cerita Dewi Sekardadu. SULUK: Jurnal Bahasa, Sastra, Dan Budaya, 2(2), 74-90. https://doi.org/10.15642/suluk.2020.2.2.74-90

Mulder, N. (1990). Folklor Indonesia: Ilmu Gosip, Dongéng, dan Lain Lain [Indonesian Folklore: The Study of Gossip, Folktales, and Other Things]. By James Danandjaja. Jakarta: Pustaka Grafitipers, 1986. Pp. xii, 238. Bibliography, Index. [In Indonesian.]. Journal of Southeast Asian Studies, 21(2). https://doi.org/10.1017/s0022463400003374

Ngationo, A. (2018). Peranan Raden Patah dalam Mengembangkan Kerajaan Demak Pada Tahun 14781518. Kalpataru: Jurnal Sejarah Dan Pembelajaran Sejarah, 4(1). https://doi.org/10.31851/ kalpataru.v4i1.2445

Notonegoro, N. (1975). Pancasila Secara Utuh Populer. Jakarta: Pancoran Tujuh.

Rahardjo, T. (2010). Memahami Kemajemukan Masyarakat Indonesia: Perspektif Komunikasi Antarbudaya (Diponegoro University). Retrieved from http://eprints.undip.ac.id/19642/

Rahmawati, N. (2016). Budaya Ziarah Makam Raden Ayu Putri Ontjat Tandha Wurung di Desa Terungwetan Kecamatan Krian Kabupaten Sidoarjo (UIN Sunan Ampel Surabaya). Retrieved from http:// digilib.uinsby.ac.id/12453/

Setiawan, I., Tallapessy, A., \& Subaharianto, A. (2016). Politik Identitas Etnis Pasca Reformasi: Studi Kasus Pada Komunitas Tengger dan Using. Jember.

Sukmawati, A., \& Sulistiani, S. (2015). Legendha Pasarean Raden Ayu Puri Oncat Tandha Wurung Ing Desa Terung Wetan Kabupaten Sidoarjo. Baradha, 3(3), 1-11. Retrieved from https:// jurnalmahasiswa.unesa.ac.id/index.php/baradha/article/view/13017/11897

Yusuf, M. A., \& Fidyansari, D. (2017). Kearifan Lokal Masyarakat Adat Komba. Prosiding Seminar Nasional Universitas Cokroaminoto Palopo, 354-373. Palopo: Universitas Cokroaminoto Palopo.

1 Malinowski (1954) membedakan pengertian legenda, mitos, dan dongeng. Bagi Malinowski legenda merupakan cerita yang diyakini seolah-olah sebagai kenyataan historis (Dhavamony, 1995).

2 Dalam beberapa literatur disebutkan Raden Husein atau Raden Kusen merupakan saudara tiri Raden Patah, putra dari Aria Damar, Sultan Palembang. Aria Damar sendiri merupakan putra Sulung Raja Brawijaya, raja terakhir Majapahit (Hanafiah \& Soetadji, 1996; Krisna, 2011; Ngationo, 2018). 
3 Menurut sumber prasasti Canggu 1280 Saka Terung merupakan salah satu tempat penyebarangan penting di tepi Kali Brantas. Pada masa Majapahit terdapat tiga tempat penyebarangan utama dari total 44 dan 34 anak cabang, yakni Curabhaya, Trung, dan Canggu. Pada masa kini daerah Terung terbagi menjadi dua desa, yakni (1) Terung Wetan dan (2) Terung Kulon, sekitar 5 km dari pusat Kecamatan Krian (Fitrotin \& Suparwoto, 2014).

4 Saat masih menjadi santri di Ampeldenta, Raden Husein pernah menyatakan pada Raden Patah bahwa dirinya akan mengabdi ke Majapahit. Benar saja, selepas nyantri pada Sunan Ampel Raden Husein meminta ijin kepada Raja Brawijaya untuk mengabdi pada Majapahit dan diberikan kedudukan sebagai Adipati di Terung (Ngationo, 2018). Jika dalam legenda ini disebutkan bahwa tragedi Putri Terung terjadi setelah Raden Husein melawat ke Blambangan atas perintah Demak Bintoro, maka besar kemungkinan peristiwa ini terjadi setelah keruntuhan Majapahit.

5 Rahmawati (2016) dalam Budaya Ziarah Makam Raden Ayu Putri Ontjat Tandha Wurung di Desa Terungwetan Kecamatan Krian Kabupaten Sidoarjo juga menyatakan, bahwa pemuda yang meminjamkan belati kepada Putri Terung adalah Sunan Bonang. 